\title{
A Case of Evolutionary Hypopituitarism Following Traumatic Brain Injury in Infancy
}

\section{Shinji Higuchi and Yukihiro Hasegawa*}

Department of Endocrinology and Metabolism, Tokyo Metropolitan Children's Medical Center, Japan

\section{Abstract}

Publication History:

The long-term clinical course of hypopituitarism resulting from traumatic brain injury in children is Received: October 21,2018 unclear. We here present a case involving a 31-year-old Japanese male with hypopituitarism caused by Accepted: December 05, 2018 traumatic brain injury at the age of 5 months. His height velocity began to decrease around 3 years of Published: December 07, 2018 age. At age 7, growth hormone and thyroid-stimulating hormone deficiencies were diagnosed. At age 10, hydrocortisone therapy was started, and testosterone enanthate therapy was needed at age 14 . The secretion of anterior pituitary hormones gradually decreased. We should check endocrinological tests in patients with traumatic brain injury who have retarded growth.

\section{Keywords:}

Hypopituitarism, Traumatic brain injury, Invisible pituitary stalk, Growth hormone deficiency

\section{Introduction}

Reports of hypopituitarism resulting from traumatic brain injury (TBI) have been increasing among children and adults over the past decades. In these reports, TBI-related hypopituitarism was found to manifest as either an isolated growth hormone $(\mathrm{GH})$ deficiency or combined hormone deficiency [1-7]. With regard to classical TBI among children, a complicated delivery such as a breech delivery may be a potential cause of hypopituitarism, and GH and adrenocorticotropic hormone (ACTH) deficiencies reportedly progress with age in these so-called 'classical' cases [8]. Moreover, cases with an invisible pituitary stalk and ectopic posterior pituitary bright spot on magnetic resonance imaging (MRI) have been reported [9].

To date, four prospective studies on TBI-related hypopituitarism in pediatric cases without perina-tal problems have been published [1013]; however, the study durations were generally only about one year. Further, although there are at least seven crosssectional studies [1420] with a comparatively long observational period of up to several years after the TBI episode, the long-term clinical course of postnatal TBI-related hypopituitarism from childhood to adulthood remains to be clarified.

We here present a case involving a 31-year-old Japanese male with hypopituitarism caused by TBI at the age of 5 months. The purpose of this report was to analyze the clinical and endocrinological data on this patient over a period of more than 20 years. As a result, we speculate that the secretion of $\mathrm{GH}$, thyroid-stimulating hormone (TSH), gonadotropins and ACTH gradually decreased in this patient.

\section{Case Report}

The patient was born uneventfully by spontaneous cephalic delivery at 40 weeks of gestation. Apgar scores at $1 \mathrm{~min}$ and $5 \mathrm{~min}$ were 10 . At birth, his height and weight were $53.0 \mathrm{~cm}(+1.9 \mathrm{SD})$ and $3.5 \mathrm{~kg}(+1.1$ $\mathrm{SD})$, respectively. He had no hypoglycemia during the neonatal period or infancy. Micropenis was not observed at the neonatal or infant health check-ups. At age 5 months, he was involved in a motorcycle accident and suffered severe head trauma, including a brain contusion, subdural hemorrhage, fracture of the skull base and cerebral edema, which caused loss of consciousness. He consequently underwent emergency surgery for removal of a hematoma and ventriculoatrial shunt placement at his local hospital. He remained unconscious for the following three days. Seizures developed three times on the fourth day postoperatively, at which time carbamazepine was successfully started. After these episodes, he had normal physical and mental development until the age of 3 years, when the ventriculoatrial shunt was removed. Retrospectively, a decrease in height velocity, the initial symptom, began around the age of 3 years.

At the age of 7 , he was brought to our hospital for retarded growth (Figure 1). His height was $107.4 \mathrm{~cm}(-3.4 \mathrm{SD})$ and his weight was $19.3 \mathrm{~kg}(-1.4 \mathrm{SD})$. At this time, a micropenis (stretched length: 30 $\mathrm{mm},-3.0 \mathrm{SD}$ ) was observed. Normal mental development was again documented, with no remarkable medical history other than that described above. He had no polyuria. Endocrinological tests yielded the following results: thyroid-stimulating hormone (TSH) $1.38 \mu \mathrm{U} /$ $\mathrm{mL}$, thyroxine $3.91 \mu \mathrm{g} / \mathrm{dL}$, luteinizing hormone $(\mathrm{LH})<0.1 \mathrm{mIU} / \mathrm{mL}$, follicle-stimulating hormone $(\mathrm{FSH})<0.1 \mathrm{mIU} / \mathrm{mL}$, insulin-like growth factor-1 $52 \mathrm{ng} / \mathrm{mL}$ (reference, 63-247 ng/mL) [21], GH response to arginine and insulin $1.8 \mathrm{ng} / \mathrm{mL}$ and $2.0 \mathrm{ng} / \mathrm{mL}$, respectively, and cortisol peak to insulin $12.53 \mu \mathrm{g} / \mathrm{dL}$ (Table 1). Based on these findings, GH and TSH deficiencies were diagnosed and treated with $\mathrm{GH}$ and l-thyroxine, respectively. GH deficiency was finally proved under euthyroidism at the age of 20 years. Gonadotropin deficiency was suspected but not proved since he was only seven years old. The size of the anterior pituitary gland was small, suggesting hypoplasia. The pituitary stalk was not visible on MRI, and an ectopic posterior pituitary bright spot was noted (Figure 1). At age 10, the peak cortisol response to insulin was $3.0 \mu \mathrm{g} / \mathrm{dL}$ and a diagnosis of ACTH deficiency was made (Table 1). Consequently, hydrocortisone therapy was initiated. The patient had no history of adrenal crisis before starting this therapy. Testosterone enanthate therapy was needed to induce pubertal development at age 14, when hypogonadotropic hypogonadism was confirmed ( $\mathrm{LH}, \mathrm{FSH}$, testosterone: all below "Corresponding Author: Dr. Yukihiro Hasegawa, Department of Endocrinology and Metabolism, Tokyo Metropolitan Children's Medical Center, 2-8-29 Musashidai Fuchu, 183-8561, Tokyo, Japan, Tel: +81-42-300-5111; E-mail: yhaset@gmail.com

Citation: Higuchi S, Hasegawa Y (2018) A Case of Evolutionary Hypopituitarism Following Traumatic Brain Injury in Infancy. Int J Pediatr Neonat Care 4: 144. doi: https://doi.org/10.15344/2455-2364/2018/144

Copyright: (C) 2018 Higuchi et al. This is an open-access article distributed under the terms of the Creative Commons Attribution License, which permits unrestricted use, distribution, and reproduction in any medium, provided the original author and source are credited. 
Citation: Higuchi S, Hasegawa Y (2018) A Case of Evolutionary Hypopituitarism Following Traumatic Brain Injury in Infancy. Int J Pediatr Neonat Care 4: 144. doi: https://doi.org/10.15344/2455-2364/2018/144

Page 2 of 4

the detection limit). His testicular volumes were $2 \mathrm{~mL}$ bilaterally, and his pubic hair was Tanner stage 1 at that time. After the start of GH injections, his growth rate improved, with the patient achieving a final height of $173.0 \mathrm{~cm}(+0.4 \mathrm{SD})$ at the age of 31 years (Figure 1). The heights of his father and mother were $172 \mathrm{~cm}$ and $162 \mathrm{~cm}$, respectively. His penile length was $9.0 \mathrm{~cm}$, testicular volumes were 4 $\mathrm{ml}$ bilaterally, and the pubic hair was Tanner stage 4 at that time.

\section{Discussion}

We assumed that the evolution of hypopituitarism in this case resulted from a postnatal TBI episode at the age of 5 months. In the present case, the traumatic brain injury included a brain contusion, subdural hemorrhage, fracture of the skull base and cerebral edema, which was considered severe enough to induce hypopituitarism [4]. In previous reports, TBI-related hypopituitarism resulted from severe TBI complications such as vascular thrombosis, infarction, and hemorrhage of the hypothalamic pituitary gland [22-24]. Basal skull fractures may cause direct damage to the hypothalamic-pituitary gland or may indicate a greater contrecoup component of the TBI, consequently resulting in a risk of pituitary stalk disruption [15]. The anterior pituitary is supplied solely by the hypophyseal portal vessels via the long portal vessels, which arise in and run down the free part of the pituitary stalk, having virtually no arterial supply. Thus, extensive necrosis develops if the blood supply is interrupted.

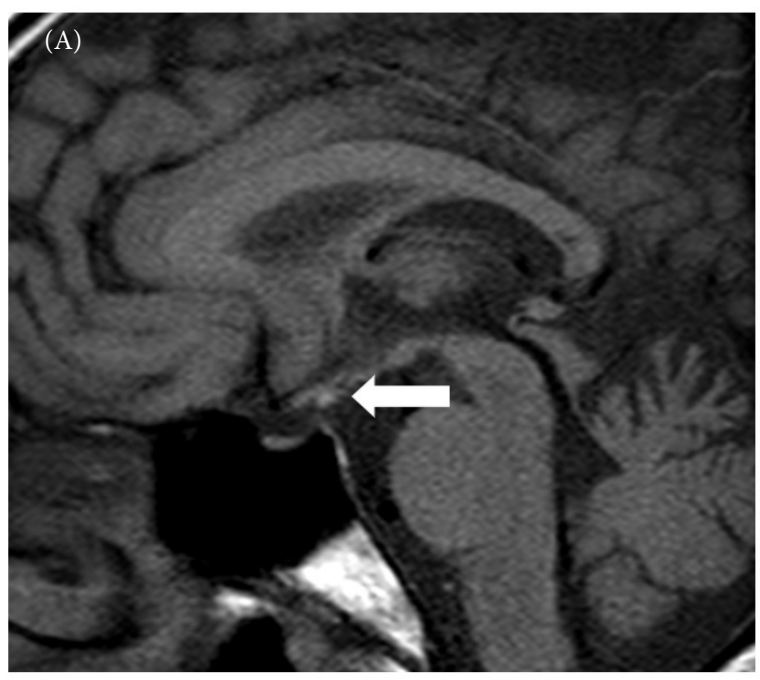

\section{Cross-sectional Growth Chart for the Boy} (0-18 years)

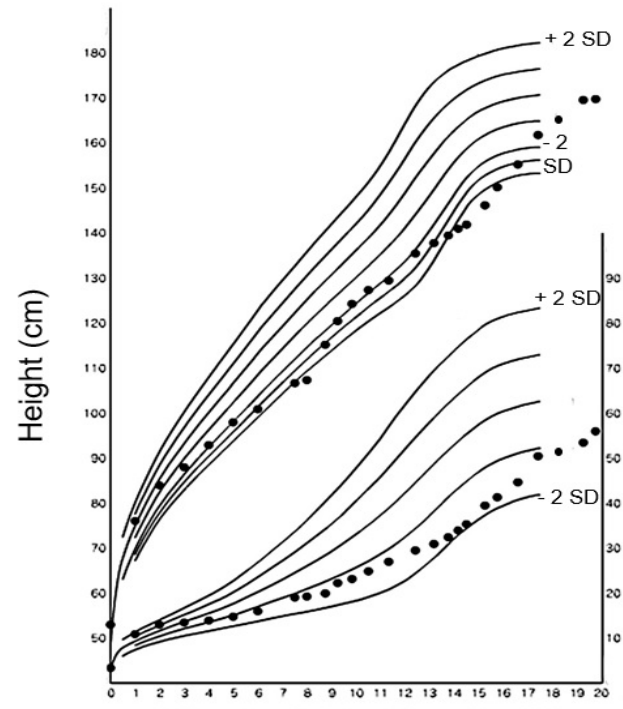

Age (Years)

Figure 1: Magnetic resonance imaging findings and growth chart of the patient.

(A): T2-weighted magnetic resonance image of the pituitary region of the patient. The pituitary stalk could not be identified, and an ectopic posterior pituitary bright spot was noted (arrow). The size of the anterior pituitary gland revealed hypoplasia.

(B): Growth chart of the patient.

\begin{tabular}{|l|c|c|c|c|c|c|c|c|c|c|c|}
\hline & & & \multicolumn{3}{|c|}{7 years } & \multicolumn{2}{c|}{10 years } & \multicolumn{2}{c|}{21 years } & \multicolumn{2}{c|}{ Reference } \\
\hline & Unit & Stimulus & Basal & Peak & Peak Time & Basal & Peak & Basal & Peak & Basal & Peak \\
\hline GH & $\mathrm{ng} / \mathrm{mL}$ & Arginine & 1.4 & 1.9 & & & & 0.8 & 1.5 & & $>6$ \\
\hline TSH & $\mu \mathrm{IU} / \mathrm{mL}$ & TRH & 1.72 & 20.53 & 90 minutes & & & & & & $10-35$ \\
\hline PRL & $\mathrm{ng} / \mathrm{mL}$ & $\mathrm{TRH}$ & 26 & 39 & & & & & & $1.7-15.4$ & increase 2 times \\
\hline LH & $\mathrm{mIU} / \mathrm{mL}$ & $\mathrm{GnRH}$ & $<0.1$ & 0.7 & & & & & & & \\
\hline FSH & $\mathrm{mIU} / \mathrm{mL}$ & $\mathrm{GnRH}$ & $<0.1$ & 0.2 & & & & & & & \\
\hline GH & $\mathrm{ng} / \mathrm{mL}$ & Insulin & 2.0 & 1.9 & & & & & & & $>6$ \\
\hline ACTH & $\mathrm{pg} / \mathrm{mL}$ & Insulin & 36 & 44 & & 21 & 23 & & & $9.8-27.3$ & $28-130.5$ \\
\hline Cortisol & $\mu \mathrm{g} / \mathrm{dL}$ & Insulin & 11.84 & 12.53 & & 2.4 & 3.0 & & & & $>19.8$ \\
\hline IGF-1 & $\mathrm{ng} / \mathrm{mL}$ & & 52 & & & 39.6 & & 86.3 & & $32-215$ & \\
\hline TSH & $\mu \mathrm{IU} / \mathrm{mL}$ & & 1.72 & & & 0.64 & & $<0.03$ & & $1.89-5.10$ & \\
\hline T3 & $\mathrm{ng} / \mathrm{mL}$ & & 0.81 & & & 0.93 & & 0.72 & & $0.75-1.08$ & \\
\hline T4 & $\mu \mathrm{g} / \mathrm{dL}$ & & 3.91 & & & 5.13 & & 9.1 & & $5-12$ & \\
\hline Testosterone & $\mathrm{ng} / \mathrm{mL}$ & & 0.1 & & & $<0.1$ & & 3.39 & & & \\
\hline
\end{tabular}

Table 1: Results of endocrinological tests at the age of 7, 10 and 21years.

GH: growth hormone; TSH: thyroid-stimulating hormone; PRL: prolactin; LH: luteinizing hormone; FSH: follicle-stimulating hormone; ACTH: adrenocorticotropic hormone; IGF: insulin-like growth factor; T3: triiodothyronine; T4: thyroxine; TRH: thyrotropin releasing hormone; GnRH: gonadotropin-releasing hormone 
The patient developed hypothalamic hypothyroidism in a functional sense. In TRH stimulation test, the peak value of TSH was $20.53 \mu \mathrm{IU} / \mathrm{mL}$ in $90 \mathrm{~min}$ (Table 1), suggesting the pattern of hypothalamic hypothyroidism. Other hypothalamic functions such as posterior pituitary hormone levels, food intake, thirst, and temperature control were intact. There were no abnormal findings of the hypothalamus on MRI. In the present case, we consider that TBI-related permanent hypopituitarism could serve as a model for the evolution of hypopituitarism due to decreased stimuli from the hypothalamus, especially when the patients show the typical MRI findings described above $[7,8]$. Indeed, mutation of the gene for Ghrhr has been identified in the mouse and results in growth failure and decreased number of somatotrrophs. In this model, the fetal somatotrophs mass is normal, and hypoplasia of the somatotrophs is evident only postnatally [25]. Furthermore, in patients with the mutation, pituitary hypoplasia has been reported postnatally [26]. Therefore, we hypothesize that the MRI findings could be interpreted as reflecting a functional disconnection between the hypothalamus and pituitary [8].

Hypopituitarism progressed with increasing age after the TBI episode in this patient. He experienced uneventful prenatal and perinatal periods and his height velocity began to decrease around the age of 3 years, possibly reflecting the evolution of GH deficiency. Neonatal screening levels of TSH and free T4 were normal. The absence of mental retardation at the age of seven years, when the treatment of hypothyroidism was started, may be consistent with the progression of TSH deficiency.

The ACTH peak level of insulin tests decreased with age. We assumed that ACTH gradually decreased. ACTH deficiency was proven at age 10 because of the low peak levels of ACTH and cortisol (Table 1). We previously reported that the serum cortisol levels tended to be high during stressful episodes in an infant with ACTH deficiency and a coexisting hypothyroid state [27]. In the present patient, the peak cortisol response on an insulin tolerance test at age 7 was obtained before starting thyroxine; thus, the cortisol peak level of insulin test was fallacious. However, he had never had episodes of adrenal crisis before starting hydrocortisone.

He had no micropenis at birth. Progression of gonadotropin deficiency was suspected at age 7 based on his micropenis and the low levels of LH and FSH, but verification was impossible during the pre-puberty stage. Progressing gonadotropin deficiency was verified at age 14 years.

Accordingly, taken together, it is reasonable to infer that $\mathrm{GH}$, and possibly other pituitary hormones such as TSH, ACTH, and gonadotropins, gradually decreased as the patient matured, and previous studies have reported a possibility of this kind of progression after pediatric TBI, leading to permanent hypopituitarism (reviewed in 4$)$.

We consider that ACTH deficiency developed later than GH deficiency in this case, because the growth velocity declined around the age of three years as in Figure 1. Since adrenal sufficiency can be fetal, a possibility of ACTH deficiency should be examined in the follow-up of patients with TBI who have retarded growth However, the order of deficiency of anterior pituitary hormones has not been extensively described so far in hypopituitarism resulting from TBI. As mentioned above, the follow-up periods after the TBI episode in the four prospective studies of pediatric TBI-related hypopituitarism of around a year are insufficient to analyze the order of the pituitary hormone deficiencies [10-13]. Late onset of ACTH deficiency has also been reported in patients showing an invisible pituitary stalk on MRI, including classical hypopituitarism patients delivered in the breech position [9].

It is reasonable to speculate that the MRI findings described above can be encountered in at least some patients with TBI-related longterm permanent hypopituitarism. The MRI findings includes a lack of visible pituitary stalk and no normal posterior lobe hypersignal in the sella turcica plus a hyperintense nodule in the region of the infundibular recess of the third ventricle, or ectopic posterior lobe. However, the long-term MRI findings of TBI-related hypopituitarism have not been discussed in most previous reports (reviewed in 4). Brain MRI in an adult case with permanent hypopituitarism showed an atrophied pituitary gland [28].

Ectopic posterior lobe could be observed in patients with genetic mutations in OTX2, SOX3, HESX1, and LXH4 [29]. However, we did not find any mutations in the previously reported genes for hypopituitarism (Kazusa Laboratory, Japan; data not shown). This negative finding does not prove but is consistent with the speculation that ectopic posterior pituitary lobe can also be observed in hypopituitarism patients after brain trauma as was illustrated before [7]. Ectopic posterior pituitary lobe is supposed to show AVP storage in the spot, presumably reflecting the functional interruption of the pituitary stalk [29].

\section{Conclusion}

In conclusion, hypopituitarism progressed with increasing age after the TBI episode in this pa-tient. Given the possibility of the evolution of TBI-related hypopituitarism in children, we should periodically examine the function of the anterior pituitary hormones when following up patients with TBI. This necessity of the long-term follow up is probably true in adult patients with TBI episodes.

\section{Competing Interests}

The authors declare that no competing interests is present.

\section{References}

1. Schneider HJ, Aimaretti G, Kreitschmann-Andermahr I, Stalla GK, Ghigo E, et al. (2007) Hypopituitarism. Lancet 369: 1461-1470.

2. Schneider HJ, Kreitschmann-Andermahr I, Ghigo E, Stalla GK, Agha A, et al. (2007) Hypothalamopituitary dysfunction following traumatic brain injury and aneurysmal subarachnoid hemorrhage: a systemat-ic review. JAMA 298: $1429-1438$.

3. Agha A, Phillips J, Thompson CJ (2007) Hypopituitarism following traumatic brain injury (TBI). Br J Neurosurg 21: 210-216.

4. Reifschneider K, Auble, BA, Rose SR (2015) Update of endocrine dysfunction following pediatric traumatic brain injury. J Clin Med 4: 1536-1560.

5. Berg C, Oeffner A, Schumm-Draeger PM, Badorrek F, Brabant G, et al. Prevalence of anterior pituitary dysfunction in patients following traumatic brain injury in a German multi-centre screening program. Exp Clin Endocrinol Diabetes 118: 139-144.

6. Ghigo E, Masel B, Aimaretti G, Léon-Carrión J, Casanueva FF, et al. (2005) Consensus guidelines on screening for hypopituitarism following traumatic brain injury. Brain Inj 19: 711-724.

7. Yamanaka C, Momoi T, Fujisawa I, Kikuchi K, Kaji M, et al. (1993) Acquired growth hormone deficiency due to pituitary stalk transection after head trauma in childhood. Eur J Pediatr 152: 99-101. 
Citation: Higuchi S, Hasegawa Y (2018) A Case of Evolutionary Hypopituitarism Following Traumatic Brain Injury in Infancy. Int J Pediatr Neonat Care 4: 144. doi: https://doi.org/10.15344/2455-2364/2018/144

Page 4 of 4

8. Miyamoto J, Hasegawa Y, Ohnami N, Onigata K, Kinoshita E, et al. (2001) Development of growth hormone and adrenocortico-tropic hormone deficiencies in patients with prenatal or perinatal-onset hypothalamic hypopituita-rism having invisible or thin pituitary stalk on magnetic resonance imaging. Endocr J 48: 355-362.

9. Kikuchi K, Fujisawa I, Momoi T, Yamanaka C, Kaji M, et al. (1988) Hypothalamic-pituitary function in growth hormone-deficient patients with pituitary stalk transection. J Clin Endocrinol Metab 67: 817-283.

10. Einaudi S, Matarazzo P, Peretta P, Grossetti R, Giordano F, et al. (2006) Hypothalamo-hypophysial dysfunction after traumatic brain injury in children and adolescents: A preliminary retrospective and prospective study. J Pediatr Endocrinol Metab 19: 691-703.

11. Kaulfers AM, Backeljauw PF, Reifschneider K, Blum S, Michaud L, et al. (2010) Endocrine dysfunction following traumatic brain injury in children. J Pediat 157: 894-899.

12. Casano-Sancho $P$, Suárez L, Ibáñez L, García-Fructuoso G, Medina J, et al. (2013) Pituitary dysfunction after traumatic brain injury in children: Is there a need for ongoing endocrine assessment? Clin Endo-crinol 79:853-858.

13. Personnier C, Crosnier H, Meyer P, Chevignard M, Flechtner I, et al. (2014) Prevalence of pituitary dysfunction after severe trau-matic brain injury in children and adolescents: a large prospective study. J Clin Endocrinol Metab 99: 2052-2060.

14. Niederland T, Makovi H, Gál V, Andréka B, Abrahám CS, et al. (2007) Abnormalities of pituitary function after traumatic brain injury in children. $J$ Neurotrauma 24: 119-127.

15. Poomthavorn P, Maixner W, Zacharin M (2008) Pituitary function in paediatric survivors of severe traumatic brain injury. Arch Dis Child 93: 133137.

16. Norwood KW, Deboer MD, Gurka MJ, Kuperminc MN, Rogol AD, et al (2010) Traumatic brain injury in children and adoles-cents: Surveillance for pituitary dysfunction. Clin Pediatr 49: 1044-1049.

17. Heather NL, Jefferies C, Hofman PL, Derraik JG, Brennan C, et al. (2012) Permanent hypopituitarism is rare after structural brain injury in early childhood. J Clin Endocrinol Metab 97: 599-604.

18. Auble BA, Bollepalli S, Makoroff K, Weis T, Khoury J, et al. (2014) Hypopituitarism in pediatric survivors of inflicted traumatic brain injury. J Neurotrauma 31: 321-326.

19. Bellone S, Einaudi S, Caputo M, Prodam F, Busti A, et al. (2013) Measurement of height velocity is an useful marker for monitoring pituitary function in patients who had traumatic brain injury. Pituitary 16: 499-506.

20. Salomón-Estébanez MA, Grau G, Vela A, Rodríguez A, Morteruel E, et al. (2014) Is routine endocrine evaluation necessary after paediatric traumatic brain injury? J Endocrinol Investig 37:143-148.

21. Isojima T, Shimatsu A, Yokoya S, Chihara K, Tanaka T, et al. (2012) Standardized centile curves and reference intervals of serum insulin-like growth factor-I (IGF-I) levels in a normal Japanese population using the LMS method. Endocr J 59: 771-780.

22. Cromptom MR (1971) Hypothalamic lesions following closed head injury. Brain 94: 165-172.

23. Daniel PM, Prichard MM, Treip CS (1959) Traumatic infarction of the anterior lobe of the pituitary gland. Lancet 2: 927-930.

24. Harper CG, Doyle D, Adams JH, Graham DI (1986) Analysis of abnormalities in pituitary gland in non-missile head injury: study of 100 consecutive cases. J Clin Pathol 39: 769-773.

25. Godfrey P, Rahal JO, Beamer WG, Copeland NG, Jenkins NA, et al. (1993) GHRH receptor of little mice contains a missense mutation in the extracellular domain that disrupts receptor function. Nat Genet 4: 227-232.

26. Netchine I, Talon P, Dastot F, Vitaux F, Goossens M, et al. (2009) Extensive Phenotypic Analysis of a Family with Growth Hormone (GH) Deficiency Caused by a Mutation in the GH-Releasing Hormone Receptor Gene. J Clin Endocrinol Metab 83: 432-436.

27. Nanao K, Miyamoto J, Anzo M, Tsukuda T, Hasegawa Y, et al. (1999) A case of congenital hypopituitarism: difficulty in the di-agnosis of ACTH deficiency due to high serum cortisol levels from a hypothyroid state. Endocr J 46: 183-186.
28. Eichler I, Frisch H, Eichler HG, Soukop W (1988) Isolated growth hormone deficiency after severe head truma. J Endocrinol Invest 11: 409-411.

29. Hasegawa Y. (2015) Let's enjoy Pediatric Endocrinology. (In Japanese) Shindan-to-Chiryosya, p32-36. 